\title{
PEMBUATAN BUBUK BAYAM DENGAN METODE FOAM MAT DRYING
}

\author{
Widarti $^{* 1}$, Indah Hartati ${ }^{1}$, Harianingsih ${ }^{2}$, Farikha Maharani ${ }^{1}$ \\ ${ }^{1}$ Jurusan Teknik Kimia Fakultas Teknik Universitas Wahid Hasyim \\ ${ }^{2}$ Jurusan Teknik Kimia Fakultas Teknik Universitas Negeri Semarang \\ *Email:wiwitwidarti292@yahoo.com
}

\begin{abstract}
Abstrak
Tanaman bayam merupakan tanaman yang memiliki berbagai kandungan mineral dan vitamin yang bermanfaat bagi kesehatan manusia. Pembuatan serbuk bayam sebagai produk siap saji akan berdampak pada meningkatnya umur simpan produk bayam, meningkatkan kepraktisan penggunaan dengan tanpa mengurangi nilai dan manfaat gizi dari bayam. Proses pembuatan serbuk bayam dapat dilakukan dengan menerapkan metode pengeringan busa (foam mat drying). Penelitian ini bertujuan untuk pengaruh perubahan suhu dan konsentrasi bahan pengisi (maltodekstrin) pada pembuatan bubuk bayam dengan metode foam mat drying. Proses pembuatan serbuk bayam dilakukan dengan menambahkan tween 80 dengan konsentrasi 6\%, maltodekstrin dengan variasi $\left(15,20\right.$ dan 25\%) serta suhu pengeringan $50-70^{\circ} \mathrm{C}$ pada puree bayam yang diperoleh dari proses penggilingan daun bayam dan air dengan rasio 1:1. Hasil penelitian menunjukkan jika pengeringan puree bayam menggunakan metode foam mat drying adalah metode yang efektif karena laju proses pengeringan menggunakan metode foam mat drying lebih cepat bila dibandingkan proses pengeringan konvensional. Laju proses pengeringan dengan metode foam mat drying berlangsung cepat pada waktu 0-90 menit. Penambahan maltodekstrin sebanyak $15 \%$ pada proses pengeringan dengan suhu $50-70^{\circ} \mathrm{C}$, mampu menghasilkan serbuk bayam dengan kadar air yang lebih rendah bila dibandingkan penggunaan maltodekstrin dengan konsentrasi 20 dan 25\%. Serbuk bayam dengan kadar air $4 \%$ mampu dihasilkan dari proses pengeringan dengan metode foam mat drying pada suhu $60^{\circ} \mathrm{C}$ dengan penambahan tween 80 sebesar $6 \%$ dan maltodekstrin dengan konsentrasi $15 \%$.
\end{abstract}

Kata Kunci: bayam, foam mat drying, maltodekstrin

\section{PENDAHULUAN}

Dewasa ini produk pangan yang tersedia dipasaran tidak hanya dituntut untuk dapat memenuhi gizi konsumen tetapi juga diharapkan memiliki umur simpan yang tidak singkat dan memiliki sifat siap saji. Oleh karenanya saat ini produk-produk yang siap saji banyak di teliti untuk dapat dikembangkan sebagai produk komersil. Produk siap saji umumnya bertekstur remah sehingga bisa mudah terlarut dalam air. Produk yang memiliki karakter bertekstur remah dan mudah larut dalam air adalah bubuk instan. Salah satu produk pangan yang memiliki nilai gizi tinggi dan dapat diubah menjadi produk dengan umur simpan yang lama serta bisa diubah menjadi produk siap saji adalah bayam.

Bayam (Amarantus sp) termasuk komoditas sayuran yang mengandung berbagai mineral, vitamin, serat, karetonoid, klorofil, dan senyawa phenolic yang berperan sebagai antioksidan. Mineral yang terkandung di bayam terdiri atas kalsium, magnesium, kalium, fosfor, dan zat besi, sementara jenis vitamin yang terdapat pada tamanan bayam terdiri atas vitamin $\mathrm{A}$, vitamin $\mathrm{B}$ complex, vitamin $\mathrm{C}$, dan vitamin K. Bayam juga dinyatakan mengandung beta karotin dan lutein yang sangat bagus untuk menjaga sel-sel tubuh dari efek buruk radikal bebas (Calikan Koc dan Dirim, 2018).

Menimbang kandungan mineral dan vitamin yang terdapat pada bayam, maka akan tepat jika dapat diupayakan proses produksi serbuk siap saji bayam. Pembuatan bubuk siap saji dapat dilakukan dengan teknologi tinggi dengan menggunakan alat yang canggih seperti freeze dryer dan spray dryer. Namun demikian kelemahan penggunaan teknologi tersebut adalah harga alat yang mahal yang berdampak pada tingginya biaya produksi. Berbagai proses dikembangkan dan dikaji untuk dapat menggantikan penggunaan teknologi yang berbiaya tinggi.

Metode pengeringan busa (foam mat drying) merupakan salah satu alternative proses pengeringan yang dapat diterapkan pada proses peneringan puree bayam. Foam mat drying didefinisikan sebagai teknik pengeringan produk berbentuk cair dan peka terhadap panas melalui teknik pembusaan dengan menambahkan zat pembuih (Hardy dan Jideani, 
2017; Kusumaningrum dan Hartati, 2018; Kurniasari dkk., 20119). Penggeringan adalah penggurangan kadar air bahan hingga bakteri pembusuk tidak dapat hidup dan kerusakan dapat dihindari. Penelitian ini bertujuan untuk menentukan pengaruh perubahan suhu dan konsentrasi bahan pengisi (maltodekstrin) pada pembuatan bubuk bayam dengan metode foam mat drying.

\section{METODOLOGI}

\subsection{Bahan dan Alat}

Bahan yang digunakan dalam penelitian ini adalah daun bayam, maltodekstrin, tween dan aquadest. Alat alat yang digunakan dalam penelitian ini berupa blender, neraca analitik, tray dryer dan alat-alat gelas.

\subsection{Prosedur percobaan}

Daun bayam di petik, di cuci dan dianginanginkan untuk menghilangkan air. Daun bayam ditambah air dengan rasio 1:1 (100 gr bayam : $100 \mathrm{ml}$ air) dan diblender. Untuk setiap run percobaan, sebanyak $30 \mathrm{gr}$ daun bayam yang sudah diblender halus di campur dengan bahan pembusa tween $80(6 \%)$ dan dimixer selama 8 menit. Maltodekstrin sebanyak $15 \%$, $20 \%, 25 \%$ ditambahkan kedalam campuran dan diaduk selama 3 menit. Variasi percobaaan disajikan pada Tabel 1. Puree bayam diletakkan dalam loyang yang dilapisi alumunium foil dengan ketebalan $1 \mathrm{~mm}$ dan dikeringkan menggunakan tray dryer dengan variasi suhu 50,60 dan $70^{\circ} \mathrm{C}$. Data berat diambil setiap 30 menit hingga beratnya konstan.

\begin{tabular}{lc}
$\begin{array}{l}\text { Tabel 1. Variasi percobaan pengeringan } \\
\text { serbuk bayam dengan metode foam mat } \\
\text { drying }\end{array}$ \\
\hline \multicolumn{2}{c}{ Parameter } \\
\hline Suhu $\left({ }^{\circ} \mathrm{C}\right)$ & \multicolumn{1}{c}{ Nilai } \\
Maltodekstrin $(\mathrm{w} / \mathrm{w})$ & $0,15 \%, 20 \%, 25 \%$ \\
\hline
\end{tabular}

\section{HASIL DAN PEMBAHASAN}

\subsection{Pengaruh konsentrasi maltodekstrin}

Pada percobaan pengaruh penambahan konsentrasi maltodekstrin, proses pengeringan dilakukan pada suhu $50^{\circ} \mathrm{C}, 60^{\circ} \mathrm{C}$ dan $70^{\circ} \mathrm{C}$ dengan penambahan Tween 80 sebanyak $6 \%$ serta penambahan maltodekstrin dengan variasi $15 \%, 20 \%$ dan $25 \%$. Analisa kadar air produk dilakukan pada interval waktu 30 menit. Gambar 1-3 menunjukkan perbedaaan kadar air serbuk bayam dengan diperoleh dari proses pengeringan tanpa foam dan serbuk bayam yang diperleh dari proses foam mat drying menggunakan maltodekstrin 15\%-25\% dan suhu pengeringan berturut turut $50^{\circ} \mathrm{C}, 60^{\circ} \mathrm{C}$ dan $70^{\circ} \mathrm{C}$.

Hasil penelitian menunjukkan jika kadar air dari serbuk bayam yang diperoleh dari proses pengeringan menggunakan metode foam mat drying pada suhu $50^{\circ} \mathrm{C}, 60^{\circ} \mathrm{C}$ dan $70^{\circ} \mathrm{C}$ di semua waktu pengeringan dan disemua penggunaan konsentrasi maltodekstrin yang berbeda (15-25\%) adalah lebih rendah bila dibandingkan dengan kadar air dari serbuk bayam yang diperoleh dari proses pengeringan konvensional (tanpa pembentukan foam). Hal tersebut menunjukkan jika metode foam mat drying merupakan metode pengeringan yang efektif dalam proses pengeringan puree bayam.

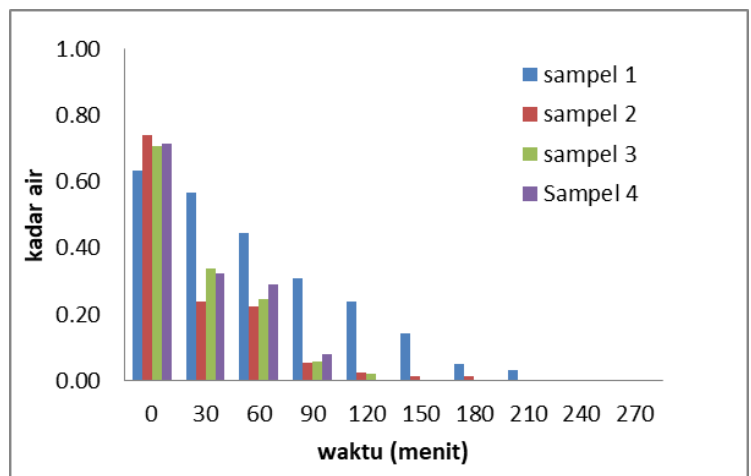

Gambar 1. Kadar air serbuk bayam yang diperoleh dari proses pengeringan dengan metode foam mat drying pada suhu $50^{\circ} \mathrm{C}$ dan variasi penambahan maltodekstrin $15-25 \%$.

\section{Keterangan : \\ Sampel $1=$ MD 0\% \\ Sampel $2=$ MD $15 \%$ \\ Sampel $3=$ MD 20\% \\ Sampel $4=$ MD 25\%}

Gambar 1-3 juga menunjukkan jika laju proses pengeringan puree bayam menggunakan metode foam mat drying berlangsung cepat untuk waktu 0-90 menit. Percepatan penghilangan kadar air pada material yang dikeringkan dinyatakan sebagai akibat dari luasnya permukaan yang berinteraksi dengan udara pengering. Pergerakan uap air juga dinyatakan terjadi sebagai akibat dari proses difusi kapiler (Sangamithra dkk., 2014). Hasil penelitian juga menunjukkan jika pada waktu 30 menit, serbuk bayam yang diperoleh dari proses pengeringan konvensioal memiliki nilai kadar air kurang lebih dua kali dari nilai kadar air serbuk bayam yang diperoleh dari proses 
pengeringan menggunakan metode foam mat drying (Gambar 1-3). Foam mat drying dinyatakan mampu mengeringkan bahan dengan temperature dan waktu pengeringan yang lebih singkat bila dibandingkan proses pengeringan bahan yang tidak dibentuk foam dengan menggunakan tipe dan kondisi pengeringan yang sama (Hardy dan Jideani, 2017; Kusumaningrum dan Hartati, 2018; Kurniasari dkk., 20119). Singkatnya waktu proses yang dibutuhkan dalam proses pengeringan dengan metode foam mat drying disebabkan luasnya permukaan yang terekspos oleh udara pengering.

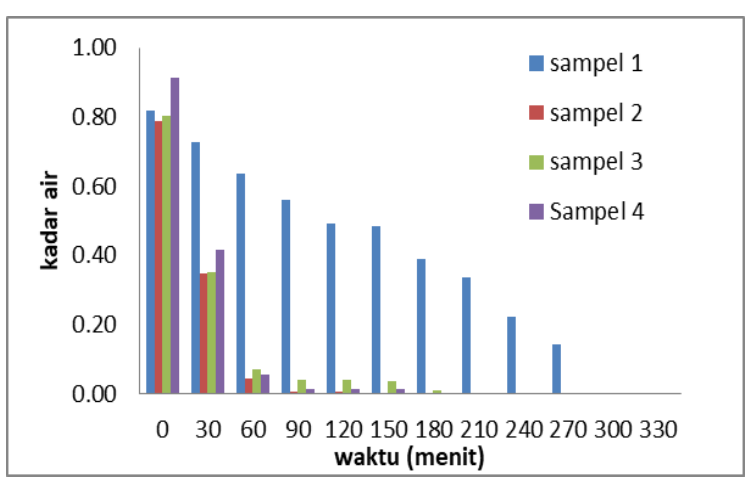

Gambar 2. Kadar air serbuk bayam yang diperoleh dari proses pengeringan dengan metode foam mat drying pada suhu $60^{\circ} \mathrm{C}$ dan variasi penambahan maltodekstrin $15-25 \%$.

\section{Keterangan :}

Sampel $1=$ MD 0\%

Sampel $2=$ MD 15\%

Sampel $3=$ MD 20\%

Sampel $4=$ MD 25\%

Gambar 1-3 juga menunjukkan jika penambahan maltodekstrin dengan kadar $15 \%$ memberikan kadar air produk yang lebih rendah bila dibandingkan dengan kadar air produk dengan penambahan maltodekstrin dengan kadar $20 \%$ dan $25 \%$. Hal tersebut menunjukkan jika maltodekstrin yang ditambahkan hanya diperlukan dalam konsentrasi yang rendah. Maltodekstrin dinyatakan mampu untuk membentuk gel dan menahan air (Darniadi, 2017). Oleh karenanya dengan penambahan maltodekstrin yang semakin tinggi maka air yang tertahan oleh maltodekstrin akan semakin banyak.

Hal tersebut mengakibatkan penggunaan maltodekstrin dengan konsentrasi yang tinggi berdampak pada tingginya kadar air produk (Gambar 1-3). Lebih lanjut, hasil penelitian menunjukkan jika kadar air produk sebesar $5.33 \%$ diperoleh dari proses pengeringan puree bayam menggunakan metode foam mat drying pada suhu $50^{\circ} \mathrm{C}$, penambahan maltodekstrin $15 \%$ serta durasi pengeringan selama 90 menit (Gambar 1).

Proses pengeringan puree bayam menggunakan metode foam mat drying pada suhu $60^{\circ} \mathrm{C}$, penambahan maltodekstrin $15 \%$ serta durasi pengeringan selama 60 menit menghasilkan produk serbuk bayam dengan kadar air sebesar $4.23 \%$ (Gambar 2). Sementara itu proses foam mat drying puree bayam pada suhu $70^{\circ} \mathrm{C}$, penambahan maltodekstrin $15 \%$ dan durasi pengeringan selama 150 menit hanya mampu menghasilkan produk serbuk bayam berkadar air 6.56\% (Gambar 3). Hasil tersebut menunjukkan jika proses pengeringan puree bayam menggunakan metode foam mat drying pada suhu $60^{\circ} \mathrm{C}$, penambahan maltodekstrin $15 \%$ serta durasi pengeringan selama 60 menit dapat dianggap sebagai kondisi proses yang relative baik bagi proses foam mat drying puree bayam.

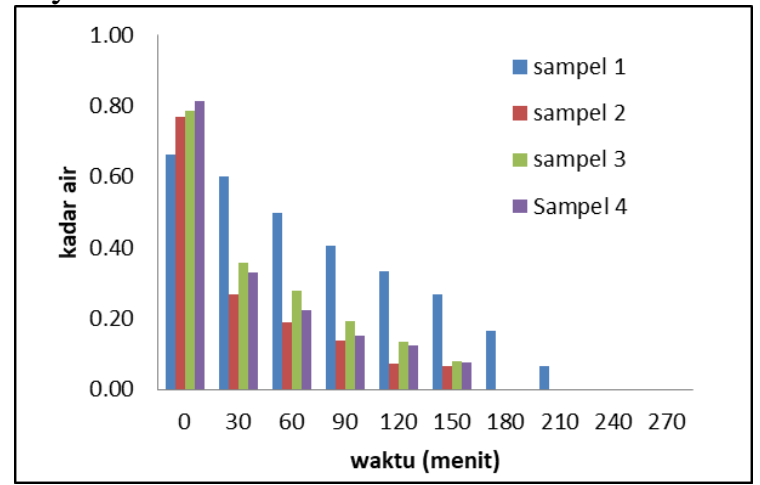

Gambar 3. Kadar air serbuk bayam yang diperoleh dari proses pengeringan dengan metode foam mat drying pada suhu $70^{\circ} \mathrm{C}$ dan variasi penambahan maltodekstrin $15-25 \%$.

\section{Keterangan :}

Sampel $1=$ MD 0\%

Sampel $2=$ MD 15\%

Sampel $3=$ MD 20\%

Sampel $4=$ MD 25\%

\subsection{Pengaruh suhu}

Proses foam mat drying puree bayam di kaji pada suhu proses yang berbeda yakni 50$70^{\circ} \mathrm{C}$. Hasil penelitian menunjukkan jika proses pengeringan pada suhu $60^{\circ} \mathrm{C}$ memberikan hasil produk dengan kadar air yang lebih rendah bila dibandingkan proses pengeringan pada suhu $50^{\circ} \mathrm{C}$ (Gambar 4). Hal tersebut menunjukkan 
jika difusivitas efektif air meningkat dari suhu $50^{\circ} \mathrm{C}$ ke $60^{\circ} \mathrm{C}$. Namun demikian, pada proses difusifitas air turun pagi pada proses pengeringan pada suhu $70^{\circ} \mathrm{C}$. Hal tersebut dapat disebabkan oleh sifat CMC (critical micelle cocncentration) dari tween yang semakin turun seiring dengan semakin tingginya temperature namun pada titik tertentu nilai CMC akan sedikit naik (Mahmood dan Al Koofeem, 2013).

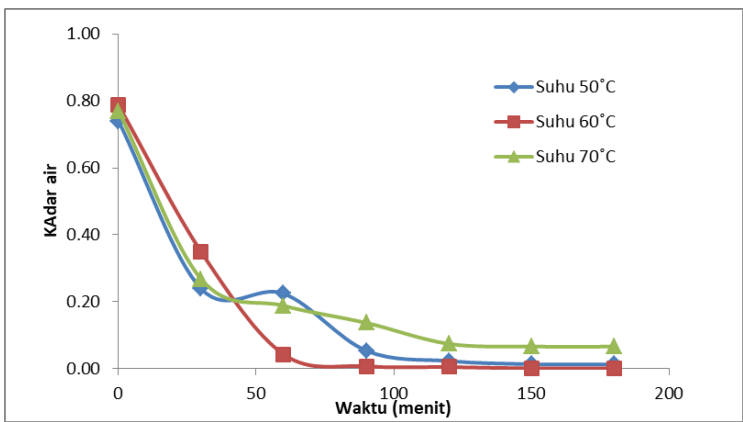

Gambar 4. Kadar air serbuk bayam yang diperoleh dari proses pengeringan dengan metode foam mat drying dengan penambahan maltodekstrin $15 \%$, penambahan tween $80(6 \%)$ dan proses pengeringan pada suhu $50-7^{\circ} \mathrm{C}$

\section{KESIMPULAN}

Hasil penelitian menunjukkan jika pengeringan puree bayam menggunakan metode foam mat drying adalah metode yang efektif, terutama bila dibandingkan dengan metode pengeringan konvensional. Laju proses pengeringan menggunakan metode foam mat drying lebih cepat bila dibandingkan proses pengeringan konvensional. Laju proses pengeringan dengan metode foam mat drying berlangsung cepat pada waktu 0-90 menit. Pada proses pengeringan dengan suhu $50-70^{\circ} \mathrm{C}$, penambahan maltodekstrin sebanyak $15 \%$ mampu menghasilkan serbuk bayam dengan kadar air yang lebih rendah bila dibandingkan penggunaan maltodekstrin dengan konsentrasi 20 dan $25 \%$. Proses pengeringan yang relative baik dengan menghasilkan serbuk bayam dengan kadar air 4\% diperoleh dari proses pengeringan dengan metode foam mat drying pada suhu $60^{\circ} \mathrm{C}$ dengan penambahan tween 80 sebesar $6 \%$ dan maltodekstrin dengan konsentrasi $15 \%$.

\section{DAFTAR PUSTAKA}

Calikan Koc G dan Dirim S.N. 2018. Spray dried spinach juice: powder properties.
Journal of Food Measurement Characteristic. Vol 12 hal 1654-1668

Darniadi, S. 2017. Optimisation of foam-mat freeze-drying conditions for blueberry powder and evaluation of powder properties. Disertasi pada University of Leeds School of Food Science and Nutrition

Hardy Z dan Jideani V.A. 2017. Foam-mat drying technology: A review, Critical Reviews in Food Science and Nutrition, 57:12, 2560-2572, DOI:10.1080/10408398.2015.1020359

Kurniasari F., Hartati I., Kurnisari L. 2019. Aplikasi Metode Foam Mat Drying Pada Pembuatan Bubuk Jahe (Zingiber Officinale). Jurnal Inovasi Teknik Kimia. Vol 4 No 1.

Kusumaningrum M. dan Hartati I. 2018. Foam Mat Drying Ampas Seduhan Teh. Cendekia Eksakta. Vol 3 No 2

Mahmood M.E., dan Al Koofeem D.A.F. 2013. Effect of Temperature Changes on Critical Micelle Concent-ration for Tween Series Surfactant. Global Journal of Science Frontier Research Chemistry.Volume 13 No 4.

Sangamithra A, Venkatachalam S, John S.G., dan Kuppuswamy K. 2014. Foam Mat Drying of Food Materials: A Review. Journal of Food Processing and Preservation. doi:10.1111/jfpp.12421 